\title{
India's Missing Women: Disentangling Cultural, Political and Economic Variables
}

\author{
Rubiana Chamarbagwala \\ Indiana University Bloomington \\ Martin Ranger \\ Indiana University Bloomington
}

December 6, 2006

This paper can be downloaded without charge from the Social Science Research Network electronic library at: http://ssrn.com/abstract=949888.

The Center for Applied Economics and Policy Research resides in the Department of Economics at Indiana University Bloomington. CAEPR can be found on the Internet at:

http://www.indiana.edu/-caepr. CAEPR can be reached via email at caepr@indiana.edu or via phone at 8D-855-4050.

(O2006 by Rubiana Chamarbagwala and Martin Ranger. All rights reserved. Short sections of text, not to exceed two paragra phs, may be quoted without explicit permission provided that full credit, including @ notice, is given to the source. 


\title{
India's missing women: disentangling cultural, political and economic variables*
}

\author{
Rubiana Chamarbagwala ${ }^{\dagger}$ \\ Indiana University
}

\author{
Martin Ranger \\ Indiana University
}

November 16th, 2006

\begin{abstract}
The severe anti-female bias in natality and child mortality that gives rise to India's missing women has been widely documented and various explanations ranging from agricultural labor demand to dowries have been offered in the literature. In general, the low demand for girls has been interpreted as a rational response to economic constraints. This paper shows the importance of culture both in determining the value of girls and in shaping parental economic constraints. We find that conservative cultural attitudes, proxied by the electoral success of religious parties, is positively correlated with anti-female bias. Moreover, higher household expenditure is negatively correlated with the number of girls. This suggests that we cannot rely on rising income levels, brought about by economic growth, to improve the demographic disadvantage faced by Indian women. Our policy recommendations therefore focus on changing attitudes of son-preference that motivate anti-female bias as much as enforcement of gender-equality legislation.
\end{abstract}

JEL Codes: J11, J16, O12

Keywords: Female Disadvantage, Mortality, Son Preference, India

\section{Introduction}

The observation that certain regions in South and East Asia exhibit both sex ratios at birth and child survival rates that are highly skewed towards boys is certainly not new. In fact, over a decade ago Amartya Sen calculated that a staggering 100 million females are missing in the region (Sen 1992), and countless articles before and since then have created an often heated debate about the causes and consequences and even the number of these missing women. In this article we examine sex ratios in India at birth and for all surviving children under five. Two of our findings are particularly important. First, while economic factors clearly

\footnotetext{
${ }^{*}$ We would like to thank Pravin Trivedi and Gerhard Glomm as well as the participants at the Indiana University Brown Bag Seminar Series for their valuable comments. As always, all remaining errors are ours.

${ }^{\dagger}$ Corresponding author: Department of Economics, Wylie Hall, Room 105, 100 S. Woodlawn, Indiana University, Bloomington, IN 47405. E-mail: rchamarb@indiana.edu.
} 
affect the number of girls born and surviving, it is not the case that higher income leads to more girls. Using a quantile estimation procedure we find that expenditure has a particularly large negative effect on lower quantiles of the child sex-ratio distribution. In as far as girls are perceived to be more expensive by parents than boys, the increasing availability of pre-natal sex screening and sex-selective abortions accompanying growing income appears to dominate possible income constraints to raising girls. Partly in consequence we contend that cultural factors are driving sex-ratios in India.

While cultural values are hard if not impossible to observe in census data, we find a statistically significant negative correlation between the number of girls born and the share of votes won by religious parties in a given district. This result should not be misconstrued as a claim of responsibility. Rather we argue that both voting for certain religious parties and a pronounced son preference are expressions of a particular conservative cultural mindset. Unless this mindset is changed, economic development might not lead to more balanced sex ratios.

India is interesting for several reasons. First, despite widespread improvements in the access to healthcare and nutrition, the relative number of girls under five has actually fallen over the last ten years from 955 for every 1000 boys in 1991 to 930 in 2001. ${ }^{1}$ Sen $(2003)$ credits the increase in availability of pre-natal sex screening technology and sex-selective abortions for this development. Moreover, sex-ratios exhibit stark inter-regional heterogeneity. Compared to an approximate reference US sex ratio at birth of 0.95 , for example, 2001 state-level rates vary from 0.78 and 0.79 in Haryana and Punjab, respectively, to 1.00 and 0.99 in Arunachal Pradesh and Mizoram. ${ }^{2}$ The map in figure 1 reveals a striking geographic pattern with the lowest number of girls born in the North-Western parts of India. This development is problematic as the shortage of women for marriage does not seem to have led to a general rise in their bargaining power both before and after marriage, contrary to what might be expected. Rather, the severe lack of women in certain regions of India seems to have resulted in increased trade in "brides" between states, forced prostitution and sexual abuse of women and children. ${ }^{3}$

A wide range of explanations have been offered for the lack of girls. Drew et al. (1986) and Oster (2005b), for example, point to findings from the medical literature which suggest that women infected with the Hepatitis B virus tend to give birth to fewer girls than healthy women, with the latter attributing up to $20 \%$ of India's missing girls to the virus. Given the prevalence and distribution of Hepatitis B in India (Pulliyel 2006) we believe that Oster (2005b) overestimates the importance of this natural cause for sex determination. ${ }^{4}$ The lack of comprehensive data for India, however, makes any empirical anlysis unreliable at best and a calculation of missing women due to the virus impossible for all intents and purposes. At any rate, even assuming that Oster (2005b)'s numbers are correct, Hepatitis B can

\footnotetext{
${ }^{1}$ See table 1.

${ }^{2}$ Figures for all Indian states are found in table 2. The international comparison is provided in table 3 .

${ }^{3}$ BBC World News, 5 April 2006.

${ }^{4}$ The argument rests on two observations. First, the Hepatitis B prevalence used by Oster (2005b) $(4.33 \%)$ considerably exceeds the estimates obtained from a meta-analysis for non-tribal women $(2.1 \%$ $1.5 \%)$ (Pulliyel 2006). Moreover, the particularly hight infection rates associated with both tribal populations (19.7\%) and particular states (Tamil Nadu, $4.4 \%$ and Karnataka, $4.5 \%$ ) are at odds with the relatively high sex ratios among those populations. A more general critique of Oster (2005b)'s thesis and her reply can be found in the exchange in the Population and Development Review (Das Gupta 2005, Oster 2006, Das Gupta 2006).
} 
account for at most one fifth of the anti-female bias. An additional $20 \%$ to $50 \%$ may be explained by discriminatory access to health services and nutrition (Oster $2005 a$ ). The question is then why girls are receiving less health care and food, and, furthermore, why this disadvantage seems to be almost exclusive to certain regions.

Economic arguments focus on the cost and benefit of raising boys and girls. Since women traditionally become part of their husband's extended family and are not expected to contribute to the financial support of their parents in old age, having sons has a positive effect on the expected standard of living of parents. This effect is less severe in regions where people practice village-level endogamy, that is where marriages tend to take place within a village, and daughters remain physically close to their parents (Agnihotri 1996, Kishor 1993, Dyson \& Moore 1983). A similar point is made by Lahiri \& Self $(2004,2005)$ who observe that endogamous practices in Southern India and even more so among the Muslim community can explain at least part of the differential sex ratios.

Dowry imposes a second direct and significant cost on the bride's parents. Although illegal, there is sufficient anecdotal evidence to support the conclusion that dowry payments are not only still demanded but that they often represent a severe financial burden for the household of the bride (Greenberg 2003). Regional differences in marriage practices and an increase in real dowry payments over the last decades may then be at least partly responsible for the observed sex ratios. While there is no comprehensive study of dowry payments, with the partial exception of Rao (1994), there is anecdotal evidence to suggest that dowry payments are substantial and that demands may have risen over the last decade or so. Amounts in the order of Rs. $1 \mathrm{~m}$ (US $\$ 21,834)^{5}$ for upper middle class marriages are not uncommon and even low-income men, such as teachers or clerks, can command as much as Rs. 300,000 (US\$ 6,550). Non-resident Indian men, who often come with US permanent residence, have prices between Rs. $5 \mathrm{~m}$ (US\$109,170) and Rs. $200 \mathrm{~m}$ (US\$ 4,366,812) ${ }^{6}$ Compared to a median monthly per capita and overall household expenditure of Rs. 140 and Rs. 843, respectively, (US\$ 3.05 and US\$ 18.40), such amounts are staggering and may provide sufficient incentives to prefer boys. ${ }^{7}$

Bardhan $(1974,1988)$ links the relatively low female birth and survival rates in the Northwest of India to agricultural practice. He observes that farmers in the regions with the lowest sex ratios grow mainly wheat and other cereals while the dominant crop in the Southern parts of India tends to be rice. If growing wheat is more male labor intensive than growing rice, perhaps due to the tasks involved, agricultural cultivation patterns could explain differential son preference across India. While this is a plausible explanation, it is not obvious that different crops have different sex-specific labor requirements and evidence from wheat-growing regions in Africa does not seem to support this argument. In any case, agricultural labor demand should not affect urban households, providing an empirical test for the hypothesis.

With rising per capita income in India it might be expected that economic constraints become less powerful and the relative number of girls increase over time. After all, richer parents do not have to rely solely on their sons for their survival in old age and - unless the income elasticities of dowry payments and wedding expenses exceed one - the relative price of girls should therefore fall. In addition,

\footnotetext{
${ }^{5}$ An exchange rate of Rs. 45.80/US\$ is used for all currency conversions.

${ }^{6}$ Source: Sunday Times of India, Mumbai Edition, December 11, 2005.

${ }^{7}$ These figures represent the median monthly expenditure using data for 593,989 individuals in 119,126 households (Consumer Expenditure Schedule, NSSO, 1999-2000).
} 
improving job opportunities for women may give them the resources to contribute to the financial support of their parents. The fact that sex-ratios have been falling as aggregate income has been rising seems thus at first inconsistent with a purely economic view of missing women. The availability of sex-selective abortion, however, complicates the picture. If the cost of aborting a daughter is lower than the cost of raising a girl, a slight increase in income might allow parents the choice to abort their daughter without, however, giving them the financial freedom to raise a girl. Although sex-selective abortions, like dowry demands, are illegal, (anecdotal) evidence suggests that they are well within the means of middle-class parents. ${ }^{8}$ A price range from Rs. 5,000 (US\$ 109) to Rs. 20,000 (US\$ 437) for illegal sexselective abortions reported by the Indian news media ${ }^{9}$ is consistent with the finding of several studies that legal early abortions are available for between Rs. 500 and Rs. 1,000 and late abortions average between Rs. 2,000 and Rs. 3,000 per case (see table 4) (Duggal 2004, Ganatra et al. 2001, Barge et al. 2004, Ramanathan et al. 2003, George et al. 2003, Centre for Operations Research and Training 1997, Parivar Seva Sanstha 2002). The relationship between average income and sex ratios is then unlikely to be linear and might include significant threshold effects.

In this paper we propose that economic constraints are often the consequence of cultural perceptions. Both dowry payments and support in old age are negotiated in a socio-cultural context and it might be argued that even the division of the majority of agricultural tasks is determined more by conventions than actual physical requirements. This argument is not new. Das Gupta (1987)'s detailed study of fertility and natality in Northern India finds that cultural variables constrain the role of women in such ways that they are an economic burden to their parents. The missing women are thus only a part of a more general framework of gender interactions in which culture and economics are inextricably linked. While these economic aspects of gender work through the parental budget constraints, non-economic factors might also be present in the utility function. Quite simply having a son might - at least ex ante - be more satisfying for parents. This is not to say that purely economic reasons are not fundamental determinants of sex ratios. Our conjecture is that the severity of economic constraints is to some extent determined by cultural variables and that, potentially, cultural traditions affect parents preferences differentially throughout India.

The paper proceeds as follows. The following section discusses briefly the socioeconomic aspects of gender selection and establishes a link between conservative culture and son preferences. Since attitudes are difficult if not impossible to extract from census data, we argue that voting behavior may be used as a proxy. Section 3 describes the data sources. The empirical analysis and a discussion of the results is found in section 4 .

\footnotetext{
${ }^{8}$ The Indian government legalized abortion under the Medical Termination of Pregnancy (MTP) Act, 1971 (amended in 2002). This law gives Indian women the right to terminate an unintended pregnancy by a registered medical practitioner in a hospital established or maintained by the Government or a place approved for the purpose of this Act by the Government. Pregnancies can be terminated for three reasons: as a health measure when there is danger to the life or risk to physical or mental health of the women; on humanitarian grounds (such as when pregnancy arises from a sex crime like rape); and where there is a substantial risk that the child, if born, would suffer from deformities and diseases. The Pre-Conception and Pre-Natal Diagnostic Techniques (Prohibition of Sex Selection) Act and Rules 1994 (as amended up to 2002) (PCPNDT Act) mandates that sex selection by any person, by any means, before or after conception, is prohibited.

${ }^{9}$ Sources: Daily Mail, online edition, July 4, 2006; Times of India, online edition, August 17, 2006.
} 


\section{Sex-selection, culture and voting behavior}

Culture can affect the worth - both economic and non-economic - of girls in many often subtle ways. Instrumental in this respect are gender relations within the Indian extended family system that are traditionally characterized by fundamental asymmetries. A lexicographic power structure with respect to sex and age underlies most intra-household transactions and decisions, with wives and daughters expected to obey decisions taken by male household members (Kandiyoti 1988). Moreover, the importance of the family lineage and reputation affect men and women differently. While this does not apply to modern Westernized families, we will argue below that it may represent an ideal for some conservative Hindu households.

In this idealized setting, sons bring new (subordinate) members to a household while daughters, who join their husband's family, are lost to their parents. This has economic consequences in as far as household heads are able to command the economic resources of its female members (including dowry payments) and it has consequences for the distribution of power within families. Since the new wives as young women occupy the lowest level of the hierarchy on top of being outsiders they increase the power of more senior female household members. The mistreatment of new wives at the hands of their mother in law, a common theme in many Bollywood movies and a reality for many women (Greenberg 2003), is an expression of this power structure. The tighter the control of male over female family members and the larger the physical distance between wives and their parents the larger one would expect the difference in worth between sons and daughters to be. ${ }^{10}$ Part of this asymmetry translates into the value of mothers in a way that even in families where financial constraints might be secondary women giving birth to sons are held in higher regard than mothers of daughters.

Traditional ideas of honor and the importance of maintaining a honorable family reputation exacerbate the situation. At the center of this lies a definition of female moral integrity that views with outright hostility any contact between women and unrelated men and a type of spillover in which the actions of a particular family member affect the honor of the entire family. This is both the consequence of a traditional female ideal which values modesty and shamefulness above all and an issue of control. Unsupervised contact between men and women of different households signals a lack of control of the household over its female members. In that sense, women requiring permission to leave the house, even if granted, is a sign of control well exercised (Derne 1994).

This has two economic consequences. Since female employment involves contact between men and women that can under most circumstances not be controlled and supervised by male family members, female wage rates are unlikely to affect employment by women in traditional households. If the work of female household members can be organized in a way that does not represent a potential threat to the family honor, say by mutual supervision of female household members, women are more likely to be economically valuable. Communal agricultural work, for example, may be one of those instances.

Moreover, in a society where informal transactions are key to economic success, a loss of honor due to the behavior of a female family member may well have serious material consequences on top of bringing shame to the family. While this is certainly true for wives, its also holds for daughters. Girls are therefore much more of a risk

\footnotetext{
${ }^{10}$ Access to communications technology may reduce the impact of physical distance for some women, but seems unlikely to be able to replace physical presence.
} 
to family honor than sons to whom the strict moral code does not generally apply.

The dowry situation has to be seen in this context of honor and expected female behavior. Firstly, the payment of a dowry is likely to be more acceptable to traditional parents both because it is seen as the norm and because dowry negotiations can easily be included in the prenuptial contract of an arranged marriage. More modern ideas of courtship and dating, which would violate the honor of a conservative family, are less amenable to dowry demands although, of course, there are exceptions. Fernandez et al. (2002)'s argument that, at least in the US and with respect to education, men are marrying women that resemble their mothers is likely to apply in this context, too. Women from Westernized families would be more likely to marry men from similar family backgrounds and dowry might not be part of the wedding arrangements. Moreover, the loss of face associated with a canceled wedding, that is with a rejected daughter, may make households embedded in a traditional cultural setting more susceptible to dowry blackmail. ${ }^{11}$

Within India, this type of family structure and value system is by no means universal. Rather it should be seen as a high-caste ideal associated with conservative Aryan (Hindu) ideology. Southern Indian Dravidian cultural norms as well as family organization in non-Hindu religions and even lower caste Hindu ideals and practices are likely to be different (Derne 1994). What this implies, however, is that one might expect lower sex ratios in families that have adopted more closely the traditional high caste family values described above, either because of the financial implications or due to the underlying value system. The North-South divide in sex ratios widely accepted in the literature could thus be an outcome of cultural differences.

Unfortunately, parental preferences and the process of cultural determination of the costs and benefits of girls relative to boys are impossible to observe directly. Variables such as female labor force participation and wages or education, which have been used in previous studies, are only imperfect proxies. While they do reflect cultural aspects to some extent, they are also affected by purely economic determinants and it is in general difficult if not impossible to disentangle the two. The endogeneity of wages and the link between education, labor force participation and expected remuneration complicate the empirical analysis. Any attempt to isolate the cultural determinants of sex-preferences, whether they operate through economic channels or affect preferences directly, therefore requires a measure of culture that is not directly affected by economics. As such measures of culture are hard to find in published data, we attempt to proxy cultural attitudes by voting behavior. More precisely we assume that a traditional cultural mind-set which leads to both higher costs of raising girls and a possible anti-female bias in preferences makes voting for particular religious parties more likely.

\subsection{Political parties and the sex ratio}

Associating particular political parties with low sex ratios is without doubt controversial and one has to point out, therefore, that our argument does not imply that the parties in question actively discriminate against women or are in any way directly responsible for sex-selection. Furthermore, this should not be misconstrued as a statement about all religious parties without qualification. Nevertheless, we believe that there exists a link between anti-female bias and an ideological proximity to the Sangh Parivar (SP), literally a "family organization" of political parties, social

\footnotetext{
${ }^{11} \mathrm{~A}$ girl that has been linked to a particular man through an engagement or in any other way is seen as less desirable and therefore less likely to find a husband in the future.
} 
institutions and paramilitary forces affiliated with the Hindu nationalist Rashtriya Swayamsevak Sangh (RSS). ${ }^{12}$

Despite the often cited requirement that funerary rites should be performed by a son, this bias does not automatically come out of Hindu religious doctrine. Rather, gender relations in the SP are shaped by a particular nationalist agenda (Hindutva) that frames the current environment in terms of the defense of Hindu India against Muslim aggression (Sarkar 1989). Based on a particular interpretation of high-caste Hindu norms and combined with a strong anti-Muslim rhetoric, that is occasionally backed up by violent action, men are seen as the dominant force in gender relations with the male Hindu warrior image featuring strongly in the ideology (Banerjee 2003) .

The role of women is more complex. On an abstract level, the body of a woman represents the Hindu motherland that is in danger of being violated by Muslim invaders as well as the purity of Hindu tradition unsullied by contact with Western ideas (Banerjee 2003). On a more physical level, Bacchetta (2004) observes that women are often described in their role as mothers and sisters and therefore as asexual beings in the official RSS propaganda. By denying their sexuality and describing them purely in terms of their relationship to men - mothers and sisters, not wives - women are essentially devoid of independent desires and personality. This is reflected in the official line on married life disseminated through seminars and literature for RSS members. Girls are supposed to acquiesce to the parental selection of a groom and self-choice is strongly discouraged (Sarkar 1989). The tradition of the docile, defenseless wife is stressed. Rather than stand up for themselves, women are supposed to obey and support their husbands and blame themselves for any marital difficulties (Sarkar 1989, Banerjee 2003). Male behavior, including infidelity, on the other hand, is often excused by pointing to biological differences both in the RSS (Banerjee 2003) and in society more generally (Pintchman 2004). These ideas and behavior tend to diminish the value and status of women in the social, religious, as well as economic spheres in India.

In order to test our hypothesis of a culturally determined sex-bias we therefore take voting for religious parties into account. ${ }^{13}$ The parties associated with the RSS are dominated by the nationally-operating Bharatiya Janata Party (BJP) and include several local parties such as the Maharashtran Shiv Sena. Although we do not possess any information on the gender attitudes of the Muslim League we include its vote share to allow for a possible connection between sex preferences and voting behavior for Muslims. Since there is no explicitly Christian political party we cannot use vote shares as proxies for conservative Christian values. The Shiromani Akali Dal, an exclusively Sikh party, has been excluded from the analysis since its electoral success is almost perfectly correlated with the share of the Sikh population in a district $(\rho=0.97)$.

Voting behavior is certainly not determined solely by cultural attitudes; and the electoral success of the BJP and its allies in the 1990s can to a large extent be attributed to disillusionment with the performance of the Congress Party led government. Time-series of election results are thus probably not good indicators of changes in cultural attitudes. Inter-regional differences in voting behavior, while reflecting local political and economic particularities, on the other hand, might be more indicative of underlying cultural differences. To be sure, not everyone who

\footnotetext{
${ }^{12}$ This link was first made by Sen (2003) who observed a geographic coincidence of low sex ratios and popularity of religious parties in the North-West of India.

${ }^{13}$ For a list of the relevant parties, please see table 6 .
} 
votes for a religious party is conservative in our sense, but conservative people are more likely to vote for religious (nationalist) parties ceteris paribus. ${ }^{14}$

\section{The Data}

The data used in the empirical analysis is compiled from three sources. Since we are interested in voting behavior which is not observable at the level of individual households we are restricted to using data collected at the district level, the highest level of disaggregation at which we can match election results, socio-economic variables and sex ratios. Including all Indian states and union territories ${ }^{15}$, we obtain data for 569 districts. With two exceptions, all dependent and explanatory variables are from the 2001 Census of India, which is originally available at the district level. ${ }^{16}$

District-level measures of income and wealth are calculated from the 55th round of the Consumer Expenditure Schedule of the National Sample Survey Organization, administered during 1999 and 2000. In particular we use the natural logarithm of the median per capita household expenditure in a district to capture the purchasing power in a particular district. ${ }^{17}$

Voting behavior is obtained from electoral data for State Legislative Assemblies published by the Election Commission of India. State Legislative Assemblies are directly elected bodies set up to carry out the administration of the government in India's states and union territories. The choice of elections for state-level institutions instead of national elections does not imply that we view these as more appropriate proxies for cultural traditions. Rather, national parliamentary constituencies are larger than state assembly constituencies and often straddle districts, making it difficult to match election results to district-level socio-economic data. Since each district has between 1 and 37 representatives in the State Legislative Assembly and consists of the same number of assembly constituencies aggregation of election results is much easier.

Using election data from the election year immediately preceding 2001 in each state we first constructed a mapping of assembly constituencies into districts using various constituency delimitation orders as well as listings of constituencies included in each district from Bose \& Singh (1988a,b,c, 2000a,b). Religious parties were identified from the list of parties registered with the Election Commission of India using their political manifestos, often posted on the internet, news media and political alliances. A list of religious parties representing nationalistic Hindu, Sikh and Muslim groups can be found in Table 6 .

\section{Results and discussion}

The parameters estimated are obtained from a log linear regression model for the ratio of girls to boys both at birth and between ages zero to five. While the latter specification has been used extensively in the literature on female disadvantage, birth and child ratios measure slightly different aspects of gender preferences. Abstracting from natural medical causes for a low sex-ratio, it can be argued that

\footnotetext{
${ }^{14}$ We have no proof for this assertion as exit polls are to our knowledge not conducted in India and individual voting behavior cannot be statistically linked to personal traits. We believe, however, that the rhetoric of political programs addresses certain parts of the population more directly than others.

${ }^{15}$ Administrative units that do not have state status.

${ }^{16} \mathrm{~A}$ description of the explanatory variables can be found in table 7 .

${ }^{17}$ Alternative measures of expenditure and their effect on the results are described in section 4.1.
} 
birth numbers are a more direct measure of sex preferences since survival rates are affected by differential susceptibility to post-natal and childhood diseases and the quality of the health care system. An opposite argument may be made equally convincingly: since the majority of Indian households do not have access to pre-natal sex-selection technology, neglect after birth and unequal access to healthcare might make the number of surviving children more representative of the desired ratio. ${ }^{18}$ As we cannot claim to be able to determine which specification is more appropriate, we report the results of both specifications.

Estimation is both by Ordinary Least Squares and Koenker \& Basset Jr. (1978)'s quantile regression model. In contrast to OLS which estimates the conditional mean of the distribution of sex ratios, a quantile regression describes a particular quantile of the distribution conditional on the observed covariates. It is thus possible to examine the effect of the exogenous variables on various parts of the distribution. We estimate the regression quantiles in $5 \%$ intervals and obtain standard errors by bootstrapping with 1000 repetitions (Koenker \& Hallock 2001). Testing for parameter constancy across quantiles we cannot reject homoscedasticity at the $5 \%$ confidence level for all explanatory variables except expenditure in the child sexratio model specification. Moreover, with the previously mentioned exception none of the coefficients of the median regression are significantly different from their OLS counterparts at 5\% confidence levels, suggesting that the OLS results are not significantly influenced by outliers. We therefore only reprt the results of the OLS regressions (tables 8 and 9 ).

The first interesting finding is the negative, statistically significant, OLS coefficient for the median monthly per capita household expenditure variable: the higher the expenditure level of the median household in a district, the lower the sex ratio. Few authors have included explicit expenditure variables in their model and this negative correlation comes as somewhat of a surprise. Moreover, the negative effect of income on the sex ratios of children under five is most severe in the left part of the distribution, whereas sex ratios above the 8 th decile are not significantly correlated with expenditure at a $10 \%$ significance level. ${ }^{19}$ An increase in the median household expenditure thus leads to an increas in the dispersion of sex ratios: districts that have lower sex ratios than expected given their covariates experience the largest reduction in sex ratios as income increases. On the other hand, expenditure has no statistically significant effect in districts where anti-female discrimination is inexplicably low. This does not hold for birth ratios where we cannot reject coefficient constancy over the range of quantiles.

The relaxation of income constraints discriminating against more expensive girls might have been expected to increase the relative number of girls born and raised. As pointed out above, however, at very low expenditure levels rising income may make sex selection affordable without giving households the resources to raise girls: abortion costs can be as low as a few hundred rupees whereas dowries are substantially higher. With an average median district expenditure of Rs. 149 (US\$ 3.25) per capita and month and a minimum and maximum of only Rs. 42 (US\$ 0.92) and Rs. 539 (US\$ 11.77) ${ }^{20}$, respectively, this hypothesis does not seem unreasonable. The possible alternative, that dowries have an income elasticity exceeding

\footnotetext{
${ }^{18}$ Anecdotal evidence about mobile ultrasound units touring the countryside, operated by enterprising individuals, suggests that sex determination at least is becoming more widely available.

${ }^{19}$ See figure 2 .

${ }^{20}$ The average exchange rate of Rs. 45.8/US\$ was used for the conversion. These figures represent the average, minimum, and maximum of the median monthly per capita household expenditure among all 569 Indian districts.
} 
one, would also be compatible with this result. Neither of these effects would be as severe in districts with high sex ratios

To examine the role of expenditure, that is of a combination of wealth and income, in more detail, we re-estimate the model with expenditure broken down by various percentiles (table 10). The results show that the negative correlation between expenditure and sex ratios is concentrated at the bottom half of the distribution, supporting our contention that the relationship is mainly caused by a relaxation of the budget constraint of the poor. An increase in wealth from very low levels makes sex-selection affordable; at higher wealth levels the constraint was not binding to begin with.

Irrespective of which explanation is the correct one, this finding has profound consequences. Ceteris paribus, as income and wealth levels rise with economic growth, one might expect the relative number of girls to fall for potentially a considerable period of time. Relying on economic growth alone as a solution to the missing women problem might thus turn out to be the wrong policy, and one that might lead to significant social upheaval as consecutive generations of men cannot find marriage partners. Due to asymmetric power structures in India, where men are traditionally in a dominant position, the relative scarcity of women is unlikely to lead to an improved bargaining position. Rather, it is more likely that the value, status, and rights of women might in fact deteriorate. "Bride abductions", wife sharing, forced prostitution and rape are likely consequences, unless existing laws are effectively enforced or the asymmetries are corrected.

A higher proportion of male workers increases the relative number of girls. In as much as higher male labor force participation leads to higher income and expenditure this result seems counter-intuitive given the negative effect of median household expenditure. While it is tempting to explain this result by a possible multicollinearity between expenditure and labor force participation, the relatively low correlation between median household expenditure and male workforce participation $(\rho=0.20)$ suggests that other factors may be important. Men who spend a significant portion of their time at work may have less control over reproductive decisions. If women then exhibit less anti-female bias than men, a contention that we do not necessarily espouse, higher sex ratios may be the result.

Female labor force participation in contrast has no statistically significant effect on sex ratios. This may be true for two reasons. First, households who contemplate sex selection might be qualitatively different from households where women consider working, due perhaps to a cultural reluctance to allow women to go to work. An increase in female employment opportunities would then be irrelevant to the sex selection decision. Alternatively, women's earning potential does not enter the decision about whether to have girls or not, either because of cognitive limitations or because it does not affect dowries and support in old age. The low female labor force participation rate of on average $28 \%$ seems to support the first conclusion.

The statistical insignificance of the proportion of literate women, that is of the number of women who have at least low levels of education, in both birth and child sex ratios is surprising, but has been observed by Das Gupta (1987) amongst others. A higher number of literate girls and women has often been interpreted as a sign of higher value for females, and therefore should be expected to be negatively correlated with discrimination against girls. This argument does not take the timing of events into account, however. It is well possible that ex ante parents prefer not to have a daughter, but once the daughter is born their optimal strategy is to provide at least some education for her in order to minimize their economic loss. If education is reasonably cheap, for example, and men desire educated wives in order to raise 
their own children, literacy might reduce dowry payments by enough to make it a worthwhile investment for parents of girls. In any case, the link between primary education and the 'value of women' is weak.

In a second argument, educated women are expected to be less culturally conservative as education is assumed to remove girls from their traditional environment and imbue them with more modern ideas. More modern women are then seen as having less of an anti-female bias, contradicting our regression result. In a cultural setting where women find themselves in a subordinate position, however, the values of women might not matter sufficiently to overcome traditions such as dowry and inability of daughters to provide for their parents in old age. Nonetheless, education affects child bearing behavior with higher levels of education leading to lower fertility. Das Gupta (1987) points out that this might have negative consequences for the sex ratio. Since parents require a certain number of sons to secure their survival in old age and, in a rural setting, work the family land, a reduction in the total number of children will lead to more anti-female bias as long as the desired number of sons is larger than half the planned number of children. In addition, literate women might find it easier to obtain information about sex-determination and abortion.

Our finding suggests that none of these arguments are globally significant. In different households literacy might affect anti-female bias in different ways, but no overall valid argument can be supported statistically. Alternatively, asymmetries between male and female household members might render very low levels of education, measured by literacy rates, ineffectual for changing behavior.

The evidence that agricultural reasons make having girls less desirable is fairly strong. Looking at birth ratios, districts with a higher proportion of male and female cultivators, that is men and women who work their own or rented land, have a significantly lower proportion of girls. This is consistent with the hypothesis that boys are more valuable as future agricultural labor force. Once political variables are included, however, the proportion of male cultivators does no longer significantly affect sex ratios. A similar picture emerges from the analysis of child sex ratios. A higher share of male cultivators is correlated with lower sex ratios as long as vote shares are not included. This suggests a possible correlation between the vote share of Hindu political parties and the number of cultivators and makes it impossible to claim with certainty that agricultural labor demand drives sex-discrimination in households that work their own land. In contrast to the birth rates model, female cultivators are not statistically significant when sex rates for children under five are examined.

The effect of the share of male agricultural laborers is unambiguously and statistically significantly negative in all model specifications. Female agricultural workers, on the other hand, do not influence sex ratios at birth and are positively correlated with sex ratios of children under five. If parents are contemplating future employment opportunities for their children, a larger labor market for women in agriculture might increase the value of girls and lead to less anti-female bias. The lack of difference between more urban and rural districts complicates the matter. Since more urban districts are likely to contain less households engaged in farming, agricultural labor shares might be picking up more general unobserved rural-urban differences in behavior.

Apparently non-economic variables are undeniably highly significant, both statistically and in terms of the magnitude of their effects. The religious makeup of a particular district, for example, has a significant effect in all model specifications. Care has to be taken, however, in interpreting the coefficients. Since the independent 
variable is the proportion of people in a given district identifying with a particular religion, the coefficients do not determine sex-ratio differentials between religious communities. Rather they have to be interpreted as the percentage change in the sex ratio related to an increase in the demographic representation of a particular religious group. The proportion of Hindus has been omitted for two reasons. First, with around $76 \%$ of the population, Hindus represent the majority of Indians and are therefore a convenient base for comparison. Moreover, since religious classification in the survey is exhaustive, the relative size of the different religious communities is necessarily highly correlated. An increase in the proportion of one religion is accompanied by a decrease in another. Unlike in the case of binary independent variables, the magnitude of the coefficients for each of the religious communities thus does not directly represent inter-religious differences in sex ratios.

Examining the correlation between the relative sizes of the different religions in a district, one finds that the correlations between the share of Hindus and any other religion far exceed all other correlations. In other words, the expansion of a particular religious group most likely leads to a reduction in the proportion of Hindus. With the share of Hindus in a particular district omitted from the regression equation, the coefficients of the other religious groups can then be interpreted as approximately representing differences in sex ratios compared to the average Hindu population. The emphasis here is on "approximately" as the correlations are not perfect.

Bearing this in mind, we cannot reject the hypothesis that a higher proportion of Muslim families leads to less skewed sex ratios despite the popular stereotypes about Muslims and their attitude towards women. Compared to Hindus, Muslims appear to perform less sex-selective abortions and do not discriminate as much against girls - at least with respect to their survival chances. This may be related to the fact that unlike all other religions in India, Muslims do not pay dowries. Instead, the bride receives a "bride price" from the family of the groom. Moreover, according to Hussain \& Billtes (2000), 22\% of marriages between Muslims are consanguineous, with first cousins being the preferred marriage partners. Almost one quarter of Muslim girls therefore remain part of their parents' extended family and can most likely help their parents in old age. Daughters are thus, if anything, less expensive.

The results for other religions is mixed. While an increase in the proportion of Christians reduces anti-female bias both at and after birth if the vote share of political parties is not included, we cannot reject that they do not have a positive effect on the sex ratio once voting is accounted for. Voting behavior is crucial in explaining this result. As it is highly unlikely that Christians would vote for Hindu religious parties, an increase in the population share of Christians, through the accompanying decrease in the relative number of Hindus, is correlated with a decrease in the vote share for the BJP and its allies. The coefficient of the proportion of Christians picks up this correlation unless vote shares are explicitly accounted for. In consequence we can claim with some confidence that the sex ratios for Hindus and Christians do not differ significantly.

The share of Buddhists has no statistically significant effect. Both an increase in the Sikh and the Jain population lead to a reduction of the number of girls relative to boys born and in the age group between zero and five years. The magnitude of the effect for Jains is particularly striking as it seems at odds with their aversion to killing even animals. Nonetheless, we are not aware of any research dealing with sex-selection or gender relations among Jains and cannot offer any explanation.

The low sex ratios for Sikhs is surprising and expected at the same time. While the official religious doctrine stresses gender equality and explicitly discourages 
dowry payments, there is ample anecdotal and systematic evidence that at least part of the Sikh community does not follow this particular aspect of religious teaching. In a detailed study of the Jat community in Northern India to which most Sikhs belong, Das Gupta (1987) points out the rigid and crass asymmetries between men and women. At the time of the study, the parents of women were expected to give gifts to their daughter and their in-laws as long as they are alive in addition to any dowry paid. They receive nothing in exchange. This one-way transfer of resources can be so extreme that they would be expected to pay even for the food they consume at their daughters new home. Women can also not inherit property and are generally excluded from participation in the public, civil and religious spheres.

Looking at scheduled castes, that is at Hindus belonging to the lowest caste, it appears that anti-female bias is more of a high-caste phenomenon at least for birth rates. Either scheduled castes do not have equal access to illegal abortions, a plausible explanation given the generally low economic status of the scheduled castes, or the traditional high-caste ideas of the appropriate female-male relationship have not been adopted by the scheduled castes. Caste differences disappear when children between zero and five years are concerned. Unless girls are more likely to die than boys, an assumption not supported by the evidence (U.S. Census Bureau 2004), neglect of girls and differential access to healthcare reduces the sex-ratio for scheduled caste households to the average level for non-scheduled-caste Hindus. This suggests that the low caste and therefore poorer families have less access to sex-selection technology but compensate for this after birth.

The importance of culture is reflected in the correlation between voting behavior and the number of girls relative to boys that are born and survive. In accordance with the observations that Muslims do not practice sex selection, we cannot reject the hypothesis that a high vote share for the Muslim League has no effect on sex ratios. As the correlation between Muslim population and the election results of the Muslim League is only 0.188 , the statistical insignificance of the Muslim League is not due to collinearities. The result then may be due to two reasons. Either, the political program of the Muslim League is not particularly attractive to conservative Muslims or conservative Islam does not translate to low sex ratios. In light of the statistical insignificance of the Muslim population the second argument is certainly plausible.

The coefficient of the vote share for parties associated with the RSS is statistically significant at the $1 \%$ level and quite large. As we have argued above, one can make the claim that the BJP and its allies have an implicitly male agenda and that people with similar beliefs might therefore be more likely to vote for them. The regression results bear out this claim at least to some extent and can be interpreted as supporting the link between cultural factors and low sex ratios.

\subsection{Robustness of Results}

Looking closer at the geographic distribution of both the sex ratios (table 2) and election results (table 5) one notices a distinct separation of India into two parts with low sex ratios as well as the electoral success of religious Hindu parties being concentrated in the North West of the country. In fact, this divide appears to be along roughly the same lines as Lahiri \& Self $(2004,2005)$ 's village endogamy versus exogamy distinction. This, then, poses the question whether the statistical link between son preference and the success of RSS-linked parties is caused by a cultural tradition particular to the Northwest of India or whether other unobservable variables underly both phenomena. 
In order to check the validity of our results, we divide India into five regions along state lines. ${ }^{21}$ The division is somewhat arbitrary, but follows loosely the language division between the Hindi-speaking North and West and the Southern and Eastern states where local languages predominate. The exception is Maharashtra which is included in the Western region even though it has its own local language. We chose this division for two reasons. First, Maharashtra appears similar to the other Northwestern states: sex-ratios are below average and the electoral success of the Shiv Sena, a Maharashtran Hindu nationalist party, links it politically to the region. ${ }^{22}$ Moreover, in contrast to Southern traditions, family structures tend to be patrilocal. Secondly, by making sure that the states with below-average sex-ratios are contained in the same regions, we maximize the probability that inter-regional differences in behavior are picked up by the regional control variable. In other words, we are defining the regions in a way that maximizes the strength of the robustness check.

Table 11 summarizes the results for the sex ratios at birth and the relative number of girls between ages zero and five. Both regional controls and political variables are included. ${ }^{23}$ As expected, the controls of the regions with below-average sex ratios (North and West) are significant a the $1 \%$ level and large. Not surprisingly also the coefficient for the vote share of Hindu and Sikh religious parties has decreased. Nevertheless, they are both still statistically significant and relatively large. This implies that even within the regions where son-preference is concentrated, districts with a high proportion of religious votes exhibit lower sex ratios. A general NorthSouth cultural divide cannot account for all the variation in sex ratios.

As mentioned in section 3 , the vote shares of the religious parties refer to state assembly election results that immediately predate the 2001 household survey used for the analysis. Since fertility decisions necessarily predate the actual observed sex ratios, using past election data appears to reflect cultural attitudes at the time of the decision more closely, if not for births observed in 2001 then at least for the sex ratio of children under five. It can be argued, however, that past elections, through the composition of the state assemblies, affect unobservables such as access to health services or vaccination programs. If religious parties are more likely to implement anti-female health policies, this rather than culture may drive our result. A similar connection can be made to lax enforcement of anti-sex-determination laws or, more generally, legislation protecting female rights. While we believe that this is unlikely, especially since the lag between the elections and our time reference does in no case exceed four years and state-level healthcare provision and law enforcement procedures are probably slow to change, we re-estimated the relevant regressions using post-2001 election data. This does not materially alter our results and conclusions (table 12).

Lastly, we examine a population growth equilibrium argument for low sex-ratios (table 13). ${ }^{24}$ If the desired marriage age for females is lower than for men and

\footnotetext{
${ }^{21}$ The Northern region includes Jammu and Kashmir, Himachal Pradesh, Punjab, Haryana, Uttar Pradesh, Uttaranchal, Delhi, Rajasthan, Madhya Pradesh, and Chattisgarh; the Western region includes Gujarat, Maharashtra, and Goa; the Southern region consists of Andhra Pradesh, Karnataka, Kerala, Tamil Nadu, and Pondicherry; the Eastern region includes Bihar, Jharkhand, West Bengal, and Orissa; the Northeastern region consists of Arunachal Pradesh, Assam, Manipur, Meghalaya, Mizoram, Nagaland, Sikkim, and Tripura.

${ }^{22}$ For a map of sex ratios, see figure 1.

${ }^{23}$ The omitted region is the Northeast.

${ }^{24}$ We use data from the Census of India, 1991, to calculate district-level population growth rates between 1991 and 2001. By matching the districts in 2001 to those in 1991, we have data for 441
} 
marriage is required, high population growth implies that each wedding cohort (consisting of older men and younger women) has an excess of women. In order to achieve equilibrium in the marriage market, sex ratios in each birth cohort have to be reduced. Since there might be some scope for arguing that a possible correlation between voting behavior and fertility decisions exists, district population growth rates were added to the original model specification. While the results provide evidence that population growth has a significant yet small impact on the ratio of boys and girls under 5 , birth rates are not affected. Neither are the coefficients for the political variables.

\section{Conclusions}

The aim of this paper has been to provide a link between economic and cultural causes for low sex ratios in India. We argue that culture enters parents' decision to discriminate against girls in two ways. First, due to culturally determined asymmetries in power and non-economic value between men and women, parental preferences might be skewed towards boys. Even if this is not the case, economic factors such as dowry payments and the inability of women to provide for their parents in old age make daughters more costly than sons and convince parents to engage in sex selection. These economic factors, we claim, are in turn influenced by cultural aspects.

Support for this argument can be found in the regression results. Unless Muslims actively discriminate against boys, a hypothesis for which there is no evidence, no religious community apart from Muslims appears to be immune to the pressures that lead to low sex ratios. The difference between Muslims and other religions is telling in this respect. The economic framework in which households operate, such as labor markets, the social security system or access to capital markets, should not be different for Muslims than all other religions. Cultural factors such as dowry payments, the relationship between in-laws and marriage patterns, on the other hand, vary between religious communities. This strengthens the argument that cultural aspects either by themselves or through economic incentives are instrumental in the anti-female bias seen in many Indian regions.

The importance of culture in the prevalent anti-female bias poses additional challenges for policy makers. Instead of relying on rising income and the availability of better economic opportunities for women to lead to a more balanced sex ratio, cultural obstacles have to be overcome. The negative effect of higher median income found in the empirical analysis makes this point quite forcefully: income growth alone is not enough to remove the anti-female bias in India. Infact, rising income provides opportunities for further discrimination against females. Thus, any policy to reverse the trend of falling sex ratios has to change the relationship between men and women.

Changing cultural norms and the framework in which men and women interact is not a trivial task and one should not forget that gender equality is a relatively new concept even in Europe and the US. Since as economists we can say very little about social engineering and the sociology of gender relations we cannot outline a comprehensive program to reduce anti-female bias in India. What seems clear is that indoctrination will have to play a big part, be it in school or through government sponsored programs. The role of TV and the cinema industry in the gender debate should in our opinion not be underestimated. With a large part of the population

districts, since several districts split into two or more smaller geographical ones during the decade. 
having access to these types of media and given the impact of movies and soapoperas on behavior and potentially cultural norms, a change in gender relations shown in movies might in the end affect cultural norms.

Such changes cannot occur over night, however, and more immediate measures have to be contemplated. Strict enforcement of existing laws is part of this. Both sex-selective abortion and dowry payments are illegal in India and it is the enforcement of the relevant laws that appears to be lacking. A combination of enforcement of existing laws and potentially new laws might be necessary to strengthen the power of women. This ranges from tough sentences for rape or forced marriage to a strong state reaction to allegations of spousal abuse. The message of the state has to be that women are equal and as valuable to men and that violence against them will not go unpunished.

\section{References}

Agnihotri, S. (1996), 'Juvenile sex ratios in India: A disaggregated analysis', Economic and Political Weekly pp. 3369-3382.

Bacchetta, P. (2004), Gender in the Hindu Nation - RSS Women as Ideologues, Kali/Women Unlimited.

Banerjee, S. (2003), 'Gender and nationalism: The masculinization of Hinduism and female political participation in India', Women's Studies International Forum 26(2), 167-179.

Bardhan, P. (1974), 'On life and death questions', Economic and Political Weekly 9, 1293-1304.

Bardhan, P. (1988), Sex disparity in child survival in rural India, in T. Srinivasa \& P. Bardhan, eds, 'Rural Poverty in South Asia', Columbia University Press, New York, pp. $473-482$.

Barge, S., Bracken, H., Elul, B., Kumar, N., Khan, W., Verma, S. \& Camlin, C. (2004), Formal and Informal Abortion Services in Rajasthan, India: Results of a Situation Analysis, Population Council.

Bose, S. B. \& Singh, V. B. (1988a), State Elections in India: Data Handbook on Vidhan Sabha Elections 1952-85: The East and Northeast, Sage.

Bose, S. B. \& Singh, V. B. (1988b), State Elections in India: Data Handbook on Vidhan Sabha Elections 1952-85: The North Part II, Sage.

Bose, S. B. \& Singh, V. B. (1988c), State Elections in India: Data Handbook on Vidhan Sabha Elections 1952-85: The South, Sage.

Bose, S. B. \& Singh, V. B. (2000a), State Elections in India: Data Handbook on Vidhan Sabha Elections 1952-85: The North Part I, Sage.

Bose, S. B. \& Singh, V. B. (2000b), State Elections in India: Data Handbook on Vidhan Sabha Elections 1952-85: The West, Sage.

Centre for Operations Research and Training (1997), Situational Analysis of MTP Services in Gujarat (1995), Maharashtra (1996), Uttar Pradesh (1997), and 
Tamil Nadu (1997), Centre for Operations Research and Training (CORT), Baroda.

Das Gupta, M. (1987), 'Selective discrimination against female children in rural Punjab, India', Population and Development Review 13(1), 77-100.

Das Gupta, M. (2005), 'Explaining asia's "missing women": A new look at the data', Population and Development Review 31(3), 529-535.

Das Gupta, M. (2006), 'Cultural versus biological factors in explaining asia's "missing women": Response to oster', Population and Development Review 32(2), 328332 .

Derne, S. (1994), 'Hindu men talk about controlling women: cultural ideas as a tool of the powerful', Sociological Perspectives 37(2), 203-227.

Drew, J., Blumberg, B. \& Robert-Lamblin, J. (1986), 'Hepatitis B virus and sex ratio of offspring in east Greenland', Human Biology 58, 115-120.

Duggal, R. (2004), 'The political economy of abortion in India: cost and expenditure patterns', Reproductive Health Matters 12, 130-137.

Dyson, T. \& Moore, M. (1983), 'On kinship structure, female autonomy, and demographic behavior in India', Population and Development Review 9, 35-60.

Fernandez, R., Fogli, A. \& Olivetti, C. (2002), Marrying your mom: Preference transmission and womens labor and education choices. New York University.

Ganatra, B., Hirve, S. \& Rao, V. (2001), 'Sex-selective abortion: Evidence from a community-based study in western India', Asia-Pacific Population Journal 16(2).

George, A., Jaymon, K. \& Babu, K. (2003), An Enquiry Into Provision of Abortion Services In Madhya Pradesh, Centre for Health and Social Sector Studies.

Greenberg, J. G. (2003), 'Criminalizing dowry deaths: the Indian experience', Journal of Gender, Social Policy and the Law 11(2), 801-846.

Hussain, R. \& Billtes, A. H. (2000), 'Sociodemographic correlates of consanguineous marriage in the Muslim population of India', Journal of Biosocial Science 32, 433-442.

Kandiyoti, D. (1988), 'Bargaining with patriarchy', Gender and Society 2, 274-289.

Kishor, S. (1993), 'May God give sons to all: gender and child mortality in India', American Sociological Review 58, 247-265.

Koenker, R. \& Basset Jr., G. (1978), 'Regression quantiles', Econometrica 46(1), 3350 .

Koenker, R. \& Hallock, K. (2001), 'Quantile regressions', Journal of Economic Perspectives 15(4), 132-156.

Lahiri, S. \& Self, S. (2004), Gender bias in education: the role of inter-household externality, dowry and other social institutions. mimeo., Southern Illinois University,. 
Lahiri, S. \& Self, S. (2005), Exogamy and bias against daughters in health-care provision: A theory and evidence from two northern states in India. mimeo., Southern Illinois University,.

Oster, E. (2005a), Excess female mortality in India: Proximate causes and policy responses. mimeo., University of Chicago.

Oster, E. (2005b), 'Hepatitis B and the case of the missing women', Journal of Political Economy 113(6), 1163-1216.

Oster, E. (2006), 'Response to Das Gupta (2005) comment: "explaining Asia's missing women - a new look at the data"', Population and Development Review fortcoming.

Parivar Seva Sanstha (2002), Abortion Research Phase II, Parivar Seva Sanstha (PSS), New Delhi.

Pintchman, T. (2004), 'Courting Krishna on the banks of the Ganges: Gender and power in a Hindu women's ritual tradition', Comparative Studies of South Asia, Africa and the Middle East 24(1), 23-32.

Pulliyel, J. (2006), 'Position paper on hepatitis b: Issues related to hepatitis b vaccination in india: Systematic review of literature'.

Ramanathan, M., Sankara Sarma, P. \& Krishnakumar, C. (2003), Situational Analysis of MTP Services in Kerala: Provider Perspectives, Achutha Menon Centre for Health Science Studies, Sree Chitra Tirunal Institute for Medical Sciences and Technology, Thiruvananthpuram, Kerala.

Rao, V. (1994), 'The rising price of husbands: a hedonic analysis of dowry increases in rural India', Journal of Political Economy 101(4), 666-677.

Sarkar, T. (1989), Women, community and nation, in P. Jeffrey \& A. Basu, eds, 'Appropriating Gender', Routledge, Londin.

Sen, A. (1992), 'Missing women', The Britsh Medical Journal 304, 586-587.

Sen, A. (2003), 'Missing women - revisited', The Britsh Medical Journal 328, 12971298.

U.S. Census Bureau (2004), Global Population Profile: 2002, International Population Reports WP/02, U.S. Government Printing Office, Washington DC. 


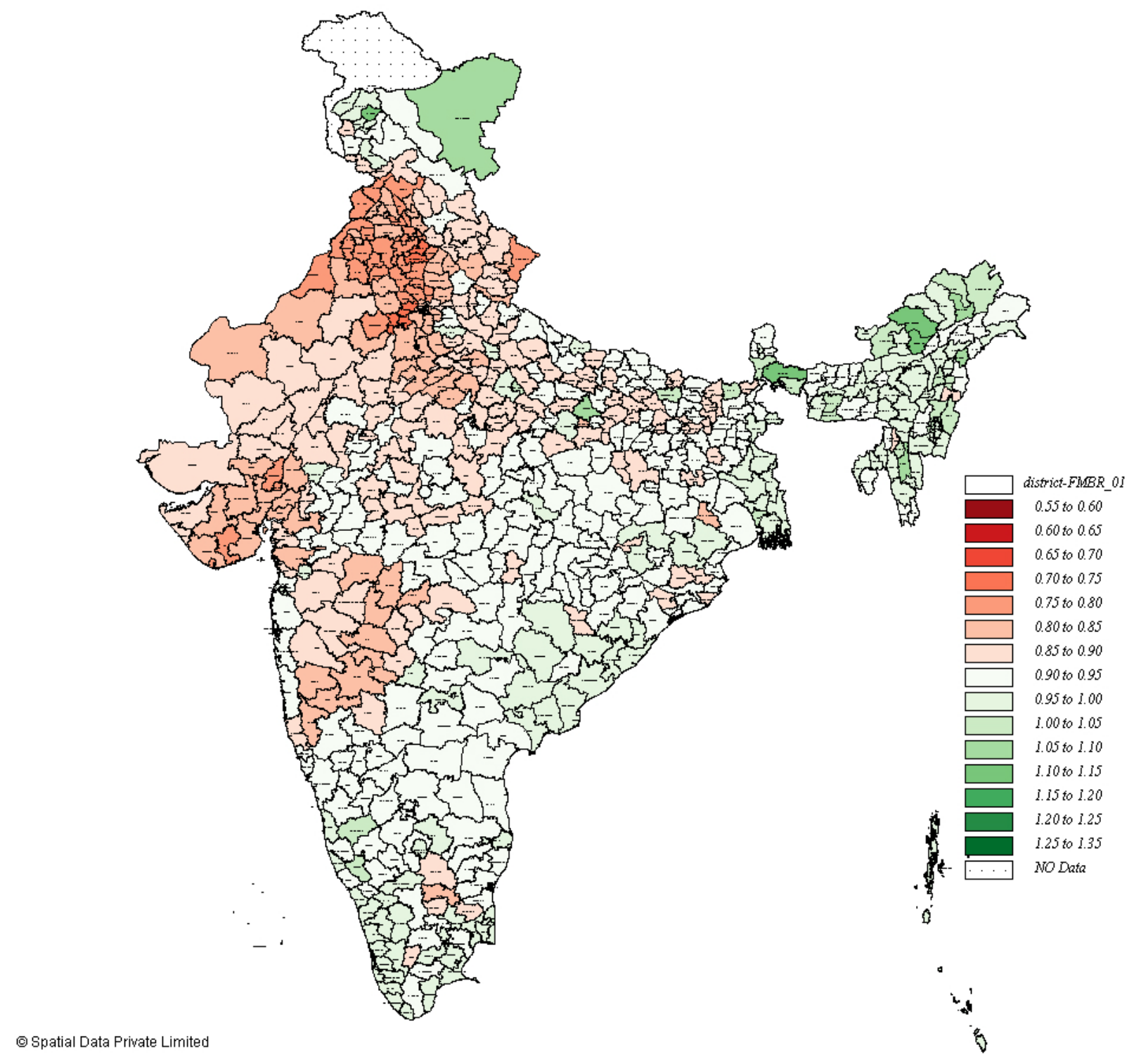

Figure 1: Female-Male Birth Ratios: Indian Districts, 2001 
Table 1: Females per 1000 Males Among Children Age 0-5 Years: India, 1961-2001

\begin{tabular}{lrrr}
\hline \multirow{2}{*}{ Year } & \multicolumn{3}{c}{ Gender Ratio } \\
\cline { 2 - 4 } & Total & Rural & Urban \\
\hline 1961 & 992 & 997 & 966 \\
1971 & 979 & 983 & 960 \\
1981 & 978 & 979 & 973 \\
1991 & 955 & 959 & 943 \\
2001 & 930 & 941 & 909 \\
\hline \multicolumn{3}{l}{ Source: Census of India, 2001. }
\end{tabular}


Table 2: Females per 1000 Males at Birth and Among Children Age 0-5 Years: Indian States, 2001

\begin{tabular}{|c|c|c|c|c|c|c|c|}
\hline \multirow[t]{2}{*}{ State/Union Territory } & \multirow[t]{2}{*}{ Region } & \multicolumn{3}{|c|}{ Child Ratio } & \multicolumn{3}{|c|}{ Birth Ratio } \\
\hline & & All India & Rural & Urban & All India & Rural & Urban \\
\hline Andhra Pradesh & South & 964 & 967 & 958 & 951 & 946 & 968 \\
\hline Arunachal Pradesh & Northeast & 975 & 971 & 994 & 997 & 991 & 1022 \\
\hline Assam & Northeast & 970 & 973 & 949 & 948 & 945 & 982 \\
\hline Bihar & East & 956 & 959 & 933 & 917 & 917 & 917 \\
\hline Chattisgarh & North & 972 & 983 & 939 & 928 & 931 & 913 \\
\hline Delhi & North & 870 & 854 & 871 & 852 & 828 & 855 \\
\hline Goa & West & 936 & 949 & 924 & 921 & 948 & 895 \\
\hline Gujarat & West & 879 & 911 & 840 & 834 & 848 & 802 \\
\hline Haryana & North & 816 & 821 & 806 & 786 & 785 & 790 \\
\hline Himachal Pradesh & North & 888 & 892 & 844 & 845 & 844 & 854 \\
\hline Jharkhand & East & 972 & 983 & 935 & 907 & 912 & 880 \\
\hline Jammu \& Kashmir & North & 932 & 954 & 870 & 951 & 949 & 966 \\
\hline Karnataka & South & 947 & 950 & 942 & 936 & 931 & 948 \\
\hline Kerala & South & 961 & 963 & 957 & 969 & 971 & 962 \\
\hline Maharashtra & West & 913 & 914 & 912 & 877 & 871 & 889 \\
\hline Manipur & Northeast & 960 & 957 & 967 & 973 & 967 & 995 \\
\hline Meghalaya & Northeast & 975 & 977 & 965 & 958 & 957 & 965 \\
\hline Mizoram & Northeast & 975 & 979 & 971 & 994 & 978 & 1014 \\
\hline Madhya Pradesh & North & 935 & 945 & 911 & 903 & 906 & 888 \\
\hline Nagaland & Northeast & 978 & 986 & 945 & 984 & 988 & 963 \\
\hline Orissa & East & 958 & 962 & 938 & 928 & 925 & 953 \\
\hline Pondicherry & South & 972 & 970 & 973 & 989 & 984 & 992 \\
\hline Punjab & North & 795 & 793 & 797 & 787 & 786 & 791 \\
\hline Rajasthan & North & 911 & 918 & 892 & 864 & 869 & 841 \\
\hline Sikkim & Northeast & 951 & 955 & 906 & 937 & 933 & 982 \\
\hline Tamil Nadu & South & 948 & 937 & 960 & 935 & 919 & 960 \\
\hline Tripura & Northeast & 966 & 969 & 953 & 973 & 975 & 960 \\
\hline Uttar Pradesh & North & 925 & 936 & 890 & 901 & 899 & 914 \\
\hline Uttaranchal & North & 904 & 916 & 870 & 853 & 852 & 857 \\
\hline West Bengal & East & 963 & 968 & 954 & 976 & 968 & 1007 \\
\hline India & & 934 & 941 & 911 & 905 & 906 & 904 \\
\hline
\end{tabular}

Source: Census of India, 2001. 
Table 3: Females per 1000 Male Births: International Comparison

\begin{tabular}{lc}
\hline Country & Gender Ratio \\
\hline All Europe & 945 \\
United Kingdom & 946 \\
Germany & 944 \\
France & 952 \\
Italy & 945 \\
Spain & 942 \\
& \\
North America & 956 \\
USA & 952 \\
Canada & 963 \\
& \\
Mexico & 966 \\
& \\
India & 905 \\
\hline Source: Data for European countries is from the World \\
Health Organization (WHO), 1950-1999; Data for North \\
America and Mexico is from WHO, 1958-1997; Data for \\
India is from the Census of India, 2001.
\end{tabular}


Table 4: The Cost of Abortion (in Rupees) in India

\begin{tabular}{lllll}
\hline State & Sector & \multicolumn{2}{c}{ Duration of Pregnancy } & Study \\
\cline { 3 - 4 } & & Under 12 Weeks & Over 20 Weeks & \\
\hline Kerala & Private & 1,266 & 5,000 & M. Ramanathan et al. (2003) \\
& Public & Free & Free & S. Barge et al. (2003) \\
Haryana & Private & 300 & 3,000 & \\
Madhya Pradesh & Public & 9 & 80 & A. George (2003) \\
Uttar Pradesh, Maharashtra, & Private & 389 & 1583 & \\
Gujarat, Tamil Nadu & Public & 209 & 775 & Center for Operations Research \\
& & 394 & 649 & and Trainng (1997) \\
Uttar Pradesh, Rajasthan & Public & 135 & & Parivar Seva Sanstha (2002) \\
\hline
\end{tabular}


Table 5: Electoral Votes for Religious Parties: Indian States, pre-2001

\begin{tabular}{|c|c|c|c|c|c|}
\hline \multirow[t]{2}{*}{ State/Union Territory } & \multirow[t]{2}{*}{ Region } & \multicolumn{4}{|c|}{ Share of Votes Won By } \\
\hline & & $\overline{\mathrm{BJP}}$ & $\begin{array}{c}\text { BJP } \\
\text { Allies }\end{array}$ & $\mathrm{SAD}$ & MUL \\
\hline Andhra Pradesh & South & 3.67 & 0.01 & 0.00 & 0.00 \\
\hline Arunachal Pradesh & Northeast & 10.83 & 0.00 & 0.00 & 0.00 \\
\hline Assam & Northeast & 10.41 & 0.03 & 0.00 & 0.00 \\
\hline Bihar & East & 11.74 & 10.13 & 0.00 & 0.00 \\
\hline Chattisgarh & North & 39.85 & 0.22 & 0.00 & 0.00 \\
\hline Delhi & North & 34.02 & 1.68 & 0.03 & 0.00 \\
\hline Goa & West & 26.15 & 15.08 & 0.00 & 0.00 \\
\hline Gujarat & West & 44.79 & 0.06 & 0.00 & 0.00 \\
\hline Haryana & North & 8.94 & 29.61 & 0.00 & 0.00 \\
\hline Himachal Pradesh & North & 39.01 & 0.11 & 0.00 & 0.00 \\
\hline Jharkhand & East & 25.12 & 4.28 & 0.00 & 0.00 \\
\hline Jammu \& Kashmir & North & 12.13 & 0.00 & 0.00 & 0.00 \\
\hline Karnataka & South & 20.68 & 13.52 & 0.00 & 0.00 \\
\hline Kerala & South & 5.48 & 0.49 & 0.00 & 7.19 \\
\hline Maharashtra & West & 14.53 & 17.38 & 0.00 & 0.00 \\
\hline Manipur & Northeast & 12.14 & 8.72 & 0.00 & 0.00 \\
\hline Meghalaya & Northeast & 5.00 & 0.00 & 0.00 & 0.00 \\
\hline Mizoram & Northeast & 2.50 & 0.28 & 0.00 & 0.00 \\
\hline Madhya Pradesh & North & 39.06 & 0.44 & 0.00 & 0.00 \\
\hline Nagaland & Northeast & 0.00 & 0.00 & 0.00 & 0.00 \\
\hline Orissa & East & 18.19 & 29.55 & 0.00 & 0.00 \\
\hline Pondicherry & South & 1.13 & 0.00 & 0.00 & 0.00 \\
\hline Punjab & North & 8.33 & 0.04 & 40.74 & 0.00 \\
\hline Rajasthan & North & 33.22 & 0.85 & 0.00 & 0.00 \\
\hline Sikkim & Northeast & 0.00 & 0.00 & 0.00 & 0.00 \\
\hline Tamil Nadu & South & 1.81 & 0.02 & 0.00 & 0.00 \\
\hline Tripura & Northeast & 5.87 & 0.00 & 0.00 & 0.00 \\
\hline Uttar Pradesh & North & 32.06 & 0.57 & 0.00 & 0.00 \\
\hline Uttaranchal & North & 40.87 & 0.00 & 0.00 & 0.00 \\
\hline West Bengal & East & 6.47 & 0.11 & 0.00 & 0.05 \\
\hline
\end{tabular}

Source: Electoral Votes in State Legislative Assemblies, Election Commission of India, pre-2001. 


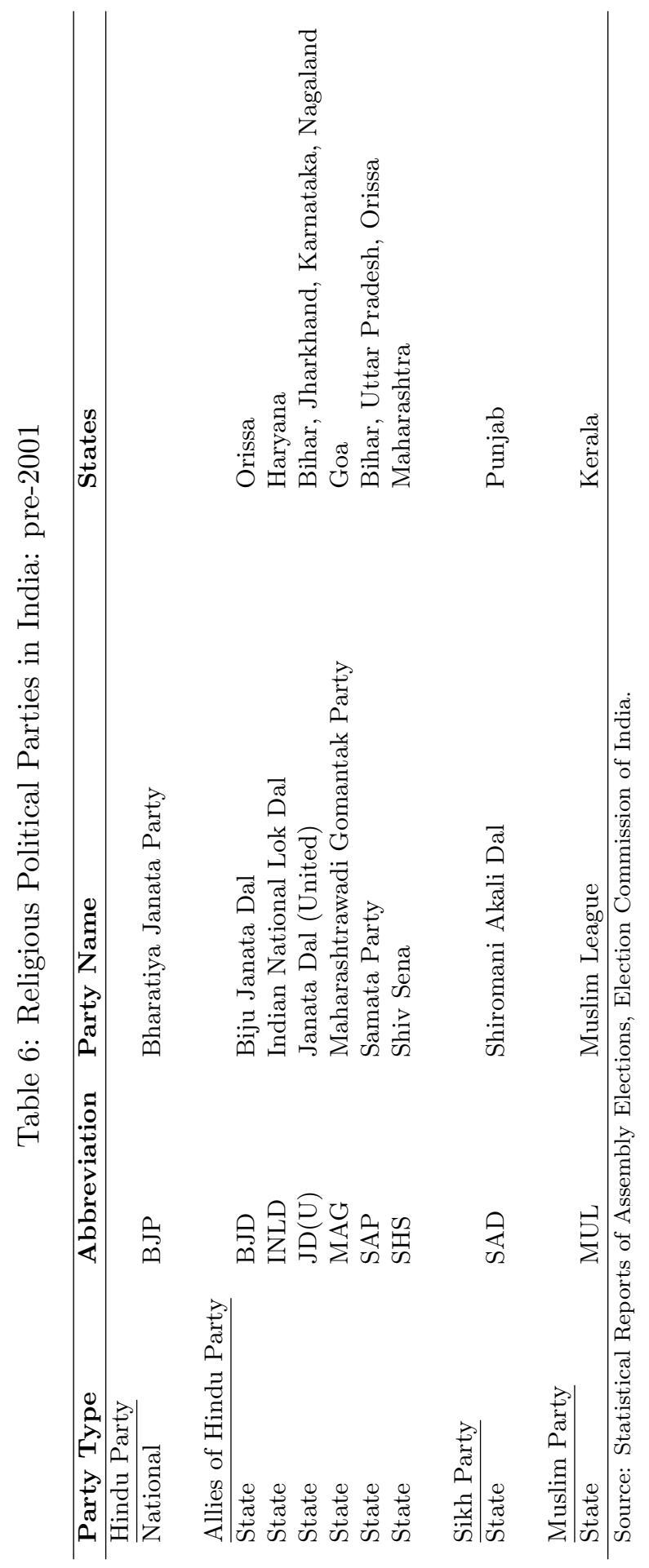


Table 7: Description of Dependent \& Explanatory Variables

\begin{tabular}{|c|c|}
\hline Variable & Description \\
\hline \multicolumn{2}{|l|}{ Dependent } \\
\hline$\overline{\text { LNFMR05 }}$ & Natural log of the female-male ratio among zero to five year olds \\
\hline LNFMBR & Natural log of the female-male birth ratio \\
\hline \multicolumn{2}{|l|}{ Explanatory } \\
\hline$\overline{\text { Hindu Votes }}$ & Share of votes won by BJP and Allies (BJD, INL, JD(U), MAG, SAP, and SHS) \\
\hline Muslim Votes & Share of votes won by MUL \\
\hline Muslims & Proportion of Muslims \\
\hline Christians & Proportion of Christians \\
\hline Sikhs & Proportion of Sikhs \\
\hline Buddhists & Proportion of Buddhists \\
\hline Jains & Proportion of Jains \\
\hline Male Voters & Proportion of male voters \\
\hline Female Voters & Proportion of female voters \\
\hline Literate Males & Proportion of literate adult males \\
\hline Literate Females & Proportion of literate adult females \\
\hline Male Workers & Proportion of adult male workers \\
\hline Female Workers & Proportion of adult female workers \\
\hline Male Cultivators & Proportion of adult male cultivators \\
\hline Female Cultivators & Proportion of adult female cultivators \\
\hline Male Agr Laborers & Proportion of adult male agricultural laborers \\
\hline Female Agr Laborers & Proportion of adult female agricultural laborers \\
\hline Urban & Proportion of population living in urban areas \\
\hline Scheduled Castes & Proportion of scheduled castes \\
\hline Scheduled Tribes & Proportion of scheduled tribes \\
\hline Income & Natural log of median monthly per capita household expenditure \\
\hline Income 5 & Natural log of 5 th percentile of monthly per capita household expenditure \\
\hline Income 25 & Natural log of 25 th percentile of monthly per capita household expenditure \\
\hline Income 50 & Natural log of 50th percentile (median) of monthly per capita household expenditure \\
\hline Income 75 & Natural log of 75 th percentile of monthly per capita household expenditure \\
\hline Income 95 & Natural log of 95 th percentile of monthly per capita household expenditure \\
\hline North & 1 if district is in Jammu and Kashmir, Himachal Pradesh, Punjab, Haryana, Uttar \\
\hline & Pradesh, Uttaranchal, Delhi, Rajasthan, Madhya Pradesh, or Chattisgarh; 0 otherwise \\
\hline West & 1 if district is in Gujarat, Maharshtra, or Goa; 0 otherwise \\
\hline South & $\begin{array}{l}1 \text { if district is in Andhra Pradesh, Karnataka, Kerala, Tamil Nadu, or Pondicherry; } \\
0 \text { otherwise }\end{array}$ \\
\hline East & 1 if district is in Bihar, Jharkhand, West Bengal, or Orissa; 0 otherwise \\
\hline Northeast & $\begin{array}{l}1 \text { if district is in Arunachal Pradesh, Assam, Manipur, Meghalaya, Mizoram, Nagaland } \\
\text { Sikkim, or Tripura, } 0 \text { otherwise }\end{array}$ \\
\hline
\end{tabular}


Table 8: OLS Regression Results Without Regional Dummies: Female-Male Child Ratios, Indian Districts, 2001

\begin{tabular}{|c|c|c|c|c|}
\hline \multirow[t]{5}{*}{ Variable } & \multicolumn{4}{|c|}{ Dependent Variable } \\
\hline & \multicolumn{2}{|c|}{ LNFMR05 } & \multicolumn{2}{|c|}{ LNFMR05 } \\
\hline & Coefficient & Standard & Coefficient & Standard \\
\hline & & Error & & Error \\
\hline & (1) & $(2)$ & (3) & (4) \\
\hline Hindu Votes & & & -0.0739 & $0.0124^{* * *}$ \\
\hline Muslim Votes & & & 0.0348 & 0.0591 \\
\hline Male Voters & 0.0369 & 0.0291 & 0.0412 & 0.0283 \\
\hline Female Voters & -0.0502 & $0.0254^{* *}$ & -0.0757 & $0.0260 * * *$ \\
\hline Literate Males & -0.1163 & $0.0496^{* *}$ & -0.0810 & $0.0487^{*}$ \\
\hline Literate Females & 0.0728 & $0.0431^{*}$ & 0.0585 & 0.0422 \\
\hline Male Workers & 0.1479 & $0.0523^{* * *}$ & 0.1291 & $0.0522^{* *}$ \\
\hline Female Workers & 0.0338 & 0.0243 & 0.0192 & 0.0244 \\
\hline Male Cultivators & -0.0573 & $0.0231^{* *}$ & -0.0319 & 0.0231 \\
\hline Female Cultivators & -0.0175 & 0.0211 & -0.0226 & 0.0202 \\
\hline Male Agr Laborers & -0.0846 & $0.0317^{* * *}$ & -0.0912 & $0.0308 * * *$ \\
\hline Female Agr Laborers & 0.0544 & $0.0202^{* * *}$ & 0.0589 & $0.0192^{* * *}$ \\
\hline Urban & -0.0108 & 0.0153 & -0.0136 & 0.0151 \\
\hline Scheduled Castes & 0.0182 & 0.0255 & 0.0091 & 0.0249 \\
\hline Scheduled Tribes & 0.0611 & $0.0123^{* * *}$ & 0.0664 & $0.0121 * * *$ \\
\hline Muslims & 0.0770 & $0.0148^{* * *}$ & 0.0574 & $0.0142^{* * *}$ \\
\hline Christians & 0.0329 & $0.0134^{* *}$ & 0.0049 & 0.0129 \\
\hline Sikhs & -0.2194 & $0.0194^{* * *}$ & -0.2361 & $0.0186^{* * *}$ \\
\hline Buddhists & 0.0143 & 0.0204 & 0.0024 & 0.0195 \\
\hline Jains & -0.8670 & $0.3220 * * *$ & -0.4796 & 0.3720 \\
\hline Income & -0.0381 & $0.0058^{* * *}$ & -0.0357 & $0.0055^{* * *}$ \\
\hline Constant & 0.0876 & $0.0329 * * *$ & 0.1026 & $0.0316^{* * *}$ \\
\hline Observations & 569 & & 569 & \\
\hline R Square & 0.6016 & & 0.6291 & \\
\hline
\end{tabular}

(4). $* * *$ Significant at $1 \%, * *$ significant at $5 \%, *$ significant at $10 \%$. 
Table 9: OLS Regression Results Without Regional Dummies: Female-Male Birth Ratios, Indian Districts, 2001

\begin{tabular}{lllll}
\hline Variable & \multicolumn{4}{c}{ Dependent Variable } \\
& \multicolumn{3}{c}{ LNFMBR } & \multicolumn{2}{c}{ LNFMBR } \\
\cline { 2 - 5 } & Coefficient & Standard & Coefficient & Standard \\
& & Error & & Error \\
& & $(2)$ & $(3)$ & $(4)$ \\
\hline Hindu Votes & & -0.1265 & $0.0162^{* * *}$ \\
Muslim Votes & -0.0711 & 0.0457 & -0.0632 & 0.0533 \\
Male Voters & 0.0630 & 0.0405 & 0.0190 & 0.0393 \\
Female Voters & -0.1656 & $0.0806^{* *}$ & -0.1076 & 0.0783 \\
Literate Males & 0.1084 & 0.0666 & 0.0878 & 0.0663 \\
Literate Females & 0.2210 & $0.0877^{* *}$ & 0.1853 & $0.0858^{* *}$ \\
Male Workers & 0.0058 & 0.0349 & -0.0184 & 0.0343 \\
Female Workers & -0.0659 & $0.0361^{*}$ & -0.0235 & 0.0360 \\
Male Cultivators & -0.0593 & $0.0288^{* *}$ & -0.0685 & $0.0270^{* *}$ \\
Female Cultivators & -0.1056 & $0.0497^{* *}$ & -0.1195 & $0.0490^{* *}$ \\
Male Agr Laborers & 0.0198 & 0.0292 & 0.0289 & 0.0280 \\
Female Agr Laborers & 0.0169 & 0.0337 & 0.0103 & 0.0329 \\
Urban & 0.0907 & $0.0448^{* *}$ & 0.0753 & $0.0427^{*}$ \\
Scheduled Castes & 0.0951 & $0.0195^{* * *}$ & 0.1047 & $0.0184^{* * *}$ \\
Scheduled Tribes & 0.0999 & $0.0239^{* * *}$ & 0.0679 & $0.0220^{* * *}$ \\
Muslims & 0.0578 & $0.0213^{* * *}$ & 0.0093 & 0.0218 \\
Christians & -0.2523 & $0.0263^{* * *}$ & -0.2809 & $0.0248^{* * *}$ \\
Sikhs & 0.0412 & 0.0334 & 0.0208 & 0.0319 \\
Buddhists & -1.5232 & $0.4277^{* * *}$ & -0.8575 & $0.4413^{*}$ \\
Jains & -0.0388 & $0.0089^{* * *}$ & -0.0347 & $0.0083^{* * *}$ \\
Income & 0.0629 & 0.0569 & 0.0900 & 0.0547 \\
Constant & 569 & & & \\
Observations & 0.4655 & & 569 & \\
R Square & 2001. Robust & standard errors are reported in columns $(2)$, and
\end{tabular}

(4). $* * *$ Significant at $1 \%, * *$ significant at $5 \%, *$ significant at $10 \%$. 


\section{Income and Child Sex Ratios}

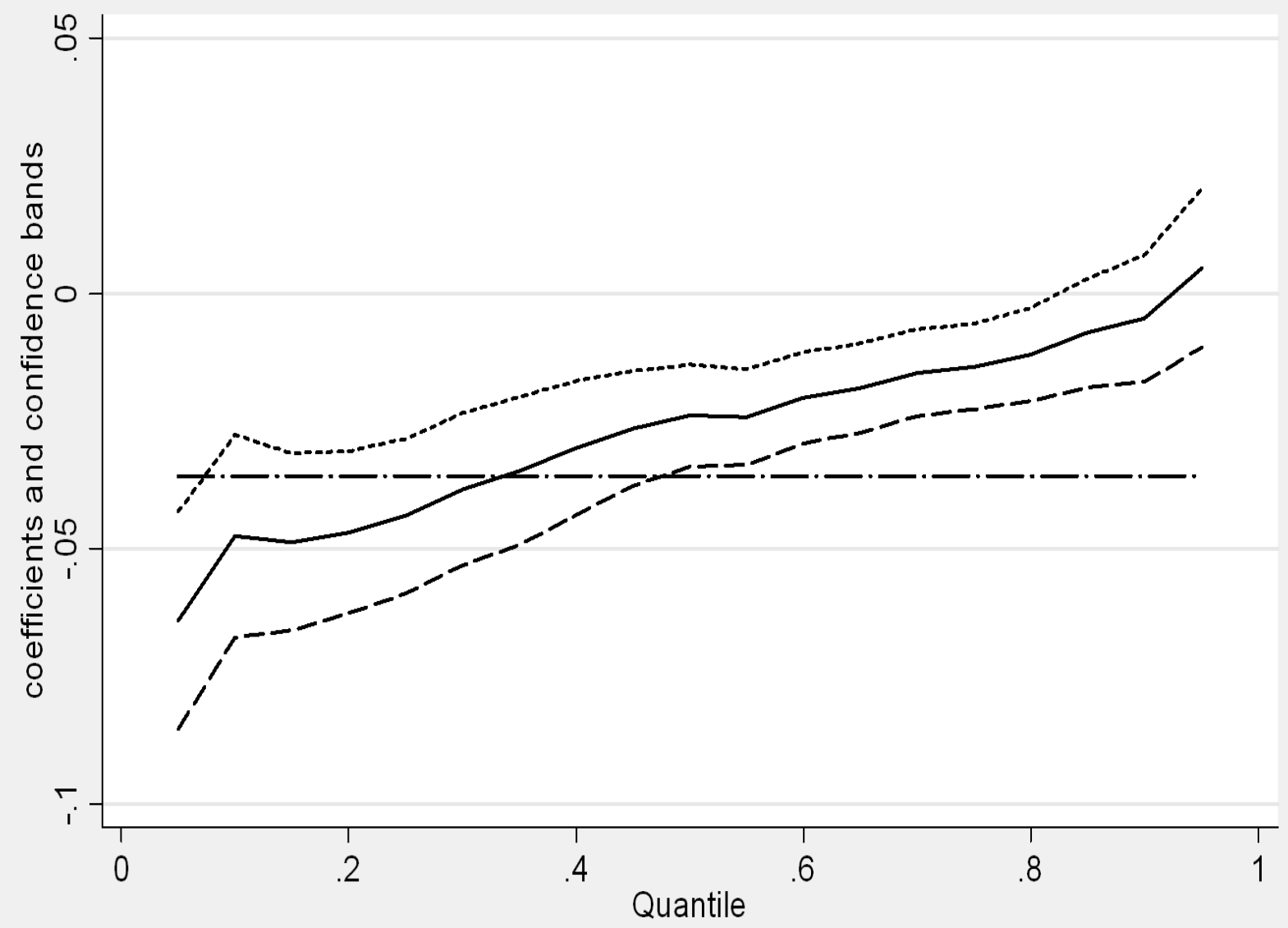

\begin{tabular}{l}
\hline - quantile_slope_coefficient \\
-..........- upper_95_confidence_band \\
-
\end{tabular}

Figure 2: Quantile Regression Coefficient: Child Sex Ratio 
Table 10: OLS Regression Results: Income Distribution Measures, Indian Districts, 2001

\begin{tabular}{|c|c|c|c|c|}
\hline \multirow[t]{5}{*}{ Variable } & \multicolumn{4}{|c|}{ Dependent Variable } \\
\hline & \multicolumn{2}{|c|}{ LNFMR05 } & \multicolumn{2}{|c|}{ LNFMBR } \\
\hline & Coefficient & Standard & Coefficient & Standard \\
\hline & & Error & & Error \\
\hline & $(1)$ & $(2)$ & $(3)$ & $(4)$ \\
\hline Hindu Votes & -0.0739 & $0.0125^{* * *}$ & -0.1245 & $0.0162^{* * *}$ \\
\hline Muslim Votes & 0.0294 & 0.0627 & 0.0020 & 0.0574 \\
\hline Male Voters & 0.0408 & 0.0278 & -0.0658 & 0.0425 \\
\hline Female Voters & -0.0767 & $0.0259^{* * *}$ & 0.0161 & 0.0396 \\
\hline Literate Males & -0.0925 & $0.0504^{*}$ & -0.1347 & $0.0792^{*}$ \\
\hline Literate Females & 0.0702 & 0.0441 & 0.1158 & $0.0661^{*}$ \\
\hline Male Workers & 0.1206 & $0.0526^{* *}$ & 0.1722 & $0.0840 * *$ \\
\hline Female Workers & 0.0251 & 0.0246 & -0.0032 & 0.0338 \\
\hline Male Cultivators & -0.0285 & 0.0233 & -0.0168 & 0.0352 \\
\hline Female Cultivators & -0.0239 & 0.0202 & -0.0736 & $0.0265^{* * *}$ \\
\hline Male Agr Laborers & -0.0964 & $0.0311^{* * *}$ & -0.1375 & $0.0490 * * *$ \\
\hline Female Agr Laborers & 0.0590 & $0.0193^{* * *}$ & 0.0321 & 0.0280 \\
\hline Urban & -0.0150 & 0.0152 & 0.0057 & 0.0323 \\
\hline Scheduled Castes & 0.0076 & 0.0250 & 0.0774 & $0.0425^{*}$ \\
\hline Scheduled Tribes & 0.0611 & $0.0128 * * *$ & 0.0943 & $0.0187 * * *$ \\
\hline Muslims & 0.0608 & $0.0149 * * *$ & 0.0768 & $0.0226^{* * *}$ \\
\hline Christians & 0.0070 & 0.0139 & 0.0141 & 0.0230 \\
\hline Sikhs & -0.2322 & $0.0188^{* * *}$ & -0.2702 & $0.0249 * * *$ \\
\hline Buddhists & 0.0012 & 0.0186 & 0.0188 & 0.0297 \\
\hline Jains & -0.4021 & 0.3825 & -0.6312 & 0.4609 \\
\hline Income 5 & -0.0214 & $0.0100 * *$ & -0.0528 & $0.0187^{* * *}$ \\
\hline Income 25 & 0.0177 & 0.0201 & 0.0234 & 0.0330 \\
\hline Income 50 & -0.0397 & $0.0216^{*}$ & 0.0032 & 0.0338 \\
\hline Income 75 & 0.0094 & 0.0166 & -0.0117 & 0.0262 \\
\hline Income 95 & -0.0060 & 0.0086 & -0.0082 & 0.0127 \\
\hline Constant & 0.1206 & $0.0370 * * *$ & 0.1342 & $0.0561^{* *}$ \\
\hline Observations & 569 & & 569 & \\
\hline R Square & 0.6327 & & 0.5302 & \\
\hline
\end{tabular}

(4). *** Significant at $1 \%, * *$ significant at $5 \%, *$ significant at $10 \%$. 
Table 11: OLS Regression Results With Regional Dummies: Female-Male Child and Birth Ratios, Indian Districts, 2001

\begin{tabular}{|c|c|c|c|c|}
\hline \multirow[t]{5}{*}{ Variable } & \multicolumn{4}{|c|}{ Dependent Variable } \\
\hline & \multicolumn{2}{|c|}{ LNFMR05 } & \multicolumn{2}{|c|}{ LNFMBR } \\
\hline & Coefficient & Standard & Coefficient & Standard \\
\hline & & Error & & Error \\
\hline & (1) & $(2)$ & $(3)$ & (4) \\
\hline Hindu Votes & -0.0334 & $0.0122^{* * *}$ & -0.0666 & $0.0174^{* * *}$ \\
\hline Muslim Votes & -0.0318 & 0.0549 & -0.0809 & 0.0561 \\
\hline Male Voters & 0.0240 & 0.0292 & -0.0822 & $0.0423^{*}$ \\
\hline Female Voters & -0.0744 & $0.0275^{* * *}$ & 0.0150 & 0.0412 \\
\hline Literate Males & -0.0234 & 0.0483 & -0.0201 & 0.0747 \\
\hline Literate Females & 0.0419 & 0.0428 & 0.0582 & 0.0661 \\
\hline Male Workers & 0.0410 & 0.0515 & 0.0714 & 0.0907 \\
\hline Female Workers & 0.0294 & 0.0237 & -0.0076 & 0.0342 \\
\hline Male Cultivators & 0.0041 & 0.0228 & 0.0207 & 0.0356 \\
\hline Female Cultivators & -0.0107 & 0.0180 & -0.0506 & $0.0240^{* *}$ \\
\hline Male Agr Laborers & -0.0297 & 0.0356 & -0.0224 & 0.0575 \\
\hline Female Agr Laborers & 0.0444 & $0.0207^{* *}$ & 0.0056 & 0.0302 \\
\hline Urban & -0.0021 & 0.0148 & 0.0264 & 0.0335 \\
\hline Scheduled Castes & -0.0120 & 0.0274 & 0.0471 & 0.0498 \\
\hline Scheduled Tribes & 0.0709 & $0.0127 * * *$ & 0.1117 & $0.0192^{* * *}$ \\
\hline Muslims & 0.0766 & $0.0141^{* * *}$ & 0.0941 & $0.0226^{* * *}$ \\
\hline Christians & -0.0226 & 0.0140 & -0.0290 & 0.0232 \\
\hline Sikhs & -0.1926 & $0.0185^{* * *}$ & -0.2200 & $0.0249 * * *$ \\
\hline Buddhists & 0.0261 & 0.0268 & 0.0510 & 0.0425 \\
\hline Jains & 0.0051 & 0.3586 & -0.1839 & 0.3929 \\
\hline Income & -0.0261 & $0.0056^{* * *}$ & -0.0222 & $0.0092^{* *}$ \\
\hline North & -0.0283 & $0.0082^{* * *}$ & -0.0420 & $0.0139 * * *$ \\
\hline South & 0.0078 & 0.0073 & 0.0082 & 0.0148 \\
\hline East & -0.0049 & 0.0074 & -0.0142 & 0.0136 \\
\hline West & -0.0460 & $0.0086^{* * *}$ & -0.0694 & $0.0144^{* * *}$ \\
\hline Constant & 0.0585 & $0.0322^{*}$ & 0.0307 & 0.0564 \\
\hline Observations & 569 & & 569 & \\
\hline R Square & 0.6687 & & 0.5651 & \\
\hline
\end{tabular}


Table 12: OLS Regression Results: Post-2001 Electoral Data, Indian Districts, 2001

\begin{tabular}{|c|c|c|c|c|}
\hline \multirow[t]{5}{*}{ Variable } & \multicolumn{4}{|c|}{ Dependent Variable } \\
\hline & \multicolumn{2}{|c|}{ LNFMR05 } & \multicolumn{2}{|c|}{ LNFMBR } \\
\hline & Coefficient & Standard & Coefficient & Standard \\
\hline & & Error & & Error \\
\hline & (1) & $(2)$ & $(3)$ & (4) \\
\hline Hindu Votes - Post & -0.0724 & $0.0132^{* * *}$ & -0.1234 & $0.0194^{* * *}$ \\
\hline Muslim Votes - Post & 0.0378 & 0.0589 & 0.0144 & 0.0554 \\
\hline Male Voters - Post & 0.0329 & 0.0282 & -0.0775 & $0.0428^{*}$ \\
\hline Female Voters - Post & -0.0618 & $0.0253^{* *}$ & 0.0429 & 0.0405 \\
\hline Literate Males & -0.0480 & 0.0502 & -0.0518 & 0.0812 \\
\hline Literate Females & 0.0341 & 0.0431 & 0.0465 & 0.0665 \\
\hline Male Workers & 0.1493 & $0.0501^{* * *}$ & 0.2198 & $0.0824^{* * *}$ \\
\hline Female Workers & 0.0253 & 0.0238 & -0.0081 & 0.0330 \\
\hline Male Cultivators & -0.0340 & 0.0225 & -0.0272 & 0.0348 \\
\hline Female Cultivators & -0.0240 & 0.0195 & -0.0709 & $0.0260 * * *$ \\
\hline Male Agr Laborers & -0.0940 & $0.0313^{* * *}$ & -0.1243 & $0.0506^{* *}$ \\
\hline Female Agr Laborers & 0.0599 & $0.0192^{* * *}$ & 0.0306 & 0.0274 \\
\hline Urban & -0.0140 & 0.0163 & 0.0097 & 0.0365 \\
\hline Scheduled Castes & 0.0000 & 0.0244 & 0.0598 & 0.0425 \\
\hline Scheduled Tribes & 0.0727 & $0.0122 * * *$ & 0.1154 & $0.0186^{* * *}$ \\
\hline Muslims & 0.0622 & $0.0144^{* * *}$ & 0.0763 & $0.0217 * * *$ \\
\hline Christians & 0.0080 & 0.0131 & 0.0148 & 0.0215 \\
\hline Sikhs & -0.2287 & $0.0185^{* * *}$ & -0.2683 & $0.0243^{* * *}$ \\
\hline Buddhists & -0.0099 & 0.0199 & -0.0001 & 0.0326 \\
\hline Jains & -0.3216 & 0.4039 & -0.5912 & 0.5091 \\
\hline Income & -0.0354 & $0.0054^{* * *}$ & -0.0341 & $0.0081^{* * *}$ \\
\hline Constant & 0.0755 & $0.0319^{* *}$ & 0.0436 & 0.0538 \\
\hline Observations & 569 & & 569 & \\
\hline R Square & 0.63 & & 0.5165 & \\
\hline
\end{tabular}

Source: Census of India, 2001. Robust standard errors are reported in columns (2) and (4). *** Significant at $1 \%,{ }^{*}$ significant at $5 \%,{ }^{*}$ significant at $10 \%$. 
Table 13: OLS Regression Results: Including Population Growth Rates, Indian Districts, 2001

\begin{tabular}{|c|c|c|c|c|}
\hline \multirow[t]{3}{*}{ Variable } & \multicolumn{4}{|c|}{ Dependent Variable } \\
\hline & \multicolumn{2}{|c|}{ LNFMR05 } & \multicolumn{2}{|c|}{ LNFMBR } \\
\hline & $\begin{array}{l}\text { Coefficient } \\
\text { (1) }\end{array}$ & $\begin{array}{l}\text { Standard } \\
\text { Error } \\
(2)\end{array}$ & $\begin{array}{l}\text { Coefficient } \\
\text { (3) }\end{array}$ & $\begin{array}{l}\text { Standard } \\
\text { Error } \\
(4)\end{array}$ \\
\hline Hindu Votes & -0.0855 & $0.0158^{* * *}$ & -0.1360 & $0.0201^{* * *}$ \\
\hline Muslim Votes & 0.0235 & 0.0593 & 0.0557 & 0.0661 \\
\hline Male Voters & 0.0593 & $0.0339^{*}$ & -0.0300 & 0.0494 \\
\hline Female Voters & -0.1105 & $0.0326^{* * *}$ & -0.0280 & 0.0492 \\
\hline Literate Males & -0.1009 & $0.0606^{*}$ & -0.1976 & $0.0976^{* *}$ \\
\hline Literate Females & 0.0601 & 0.0498 & 0.1336 & $0.0776^{*}$ \\
\hline Male Workers & 0.1236 & $0.0584^{* *}$ & 0.1550 & 0.0944 \\
\hline Female Workers & 0.0249 & 0.0277 & -0.0113 & 0.0410 \\
\hline Male Cultivators & -0.0484 & $0.0269 *$ & -0.0348 & 0.0425 \\
\hline Female Cultivators & -0.0114 & 0.0234 & -0.0745 & $0.0317^{* *}$ \\
\hline Male Agr Laborers & -0.0872 & $0.0371^{* *}$ & -0.0925 & 0.0564 \\
\hline Female Agr Laborers & 0.0506 & $0.0235^{* *}$ & 0.0013 & 0.0315 \\
\hline Urban & -0.0024 & 0.0173 & 0.0264 & 0.0418 \\
\hline Scheduled Castes & 0.0360 & 0.0262 & 0.1304 & $0.0461^{* * *}$ \\
\hline Scheduled Tribes & 0.0693 & $0.0134^{* * *}$ & 0.1047 & $0.0203^{* * *}$ \\
\hline Muslims & 0.0670 & $0.0218^{* * *}$ & 0.0300 & 0.0349 \\
\hline Christians & 0.0090 & 0.0150 & 0.0145 & 0.0256 \\
\hline Sikhs & -0.2525 & $0.0226^{* * *}$ & -0.3249 & $0.0319 * * *$ \\
\hline Buddhists & 0.0149 & 0.0224 & 0.0503 & 0.0356 \\
\hline Jains & -0.5684 & 0.4352 & -0.6693 & 0.4965 \\
\hline Income & -0.0350 & $0.0066^{* * *}$ & -0.0338 & $0.0099 * * *$ \\
\hline Pop Growth Rate & -0.0004 & $0.0001^{* * *}$ & -0.0003 & 0.0002 \\
\hline Constant & 0.1279 & $0.0400^{* * *}$ & 0.1534 & $0.0709 * *$ \\
\hline Observations & 441 & & 441 & \\
\hline R Square & 0.6234 & & 0.5271 & \\
\hline
\end{tabular}

(4). ${ }^{* * *}$ Significant at $1 \%,{ }^{* *}$ significant at $5 \%,{ }^{*}$ significant at $10 \%$. 